\title{
Supplementary Section
}

\section{Synergistic Elimination of $\mathrm{NO}_{\mathrm{x}}$ and Chloroaromatics on a Commercial}

\section{$\mathrm{V}_{2} \mathrm{O}_{5}-\mathrm{WO}_{3} / \mathrm{TiO}_{2}$ Catalyst: Byproducts Analyses and the $\mathrm{SO}_{2}$ Effect}

Weiyu Jiang ${ }^{\mathrm{a}}$, Yulei Yu ${ }^{\mathrm{a}}$, Feng Bi ${ }^{\mathrm{a}}$, Pengfei Sun ${ }^{\mathrm{a}}$, Xiaole Weng*a,b ${ }^{*}$ Zhongbiao Wu ${ }^{\mathrm{a}, \mathrm{b}}$

${ }^{a}$ Key Laboratory of Environment Remediation and Ecological Health, Ministry of Education, College of Environmental and Resource Sciences, Zhejiang University, 310058 Hangzhou, P. R. China.

${ }^{\mathrm{b}}$ Zhejiang Provincial Engineering Research Center of Industrial Boiler \& Furnace Flue Gas Pollution Control, 388 Yuhangtang Road, 310058 Hangzhou, P. R. China.

Corresponding author: Dr. Xiaole Weng, E-mail: xlweng@zju.edu.cn

Number of Pages: 16

Number of Figures: 7

Number of Tables: 5 


\section{S1. CATALYST CHARACTERIZATIONS}

$\mathrm{O}_{2}$-temperature-programmed oxidation (TPO) was conducted using an automatic multipurpose adsorption instrument TP-5089 (Tianjin Xianquan, China). The pretreated ( $0.1 \mathrm{~g}$, treated at $200{ }^{\circ} \mathrm{C}$ in $\mathrm{He}$ for $1 \mathrm{~h}$ ) catalyst was subjected to a flow of $5 \mathrm{vol} \% \mathrm{O}_{2} / \mathrm{He}$ $(30 \mathrm{~mL} / \mathrm{min})$ at $100^{\circ} \mathrm{C}$ until the base line remained unchanged. Thereafter, the catalyst was heated from 100 to $900^{\circ} \mathrm{C}$ at a rate of $10^{\circ} \mathrm{C} / \mathrm{min}$ to record $\mathrm{CO}_{2}(\mathrm{~m} / \mathrm{z}=44)$ desorption using a quadrupole mass spectrometer (Hiden Analytical, UK).

Surface elemental analyses were conducted using an X-ray photoelectron spectroscopy (XPS) instrument ESCALAB 250xi (Thermo Scientific, USA) with Al $\mathrm{K} \alpha$ radiation (photon energy $1486.6 \mathrm{eV}, 150 \mathrm{~W}$ ). The signal of adventitious carbon (a binding energy at $284.8 \mathrm{eV}$ ) was used to calibrate the binding energy scale for each catalyst. Curve fitting were performed using a Shirley background and a Gaussian peak shape with $20 \%$ Lorentzian character.

$\mathrm{X}$-ray powder diffraction (XRD) patterns were recorded by using a D/Max RA diffractometer (Rigaku, Japan) with $\mathrm{Cu}-\mathrm{K} \alpha$ radiation $(\lambda=0.15418 \mathrm{~nm})$ at $40 \mathrm{kV}$ and $150 \mathrm{~mA}$. All XRD patterns were obtained with scattering angles (20) ranging from $10^{\circ}$ to $80^{\circ}$ at a step size of $0.026^{\circ}$. Crystal phase of the catalysts were identified according to the JCPDS database.

Thermal Gravity (TG) and Differential Thermal Gravity (DTG) analyses for the sulfated and fresh $\mathrm{V}_{2} \mathrm{O}_{5}-\mathrm{WO}_{3} / \mathrm{TiO}_{2}$ catalyst were carried out in a static Ar atmosphere, using a TGA/DSC3+ instrument (METTLER TOLEDO, Switzerland). 10-15 mg of catalyst was analyzed between 30 and $1000{ }^{\circ} \mathrm{C}$ at a rate of $5{ }^{\circ} \mathrm{C} / \mathrm{min}$. TG and DTG analyses for the decomposition of $\mathrm{NH}_{4} \mathrm{Cl}$ were carried out in a static $\mathrm{N}_{2}$ atmosphere, using a SDT Q600 analyser (TA Instruments, USA). 10-15 mg of catalyst was analyzed between 30 and $1000{ }^{\circ} \mathrm{C}$ at a rate of $10{ }^{\circ} \mathrm{C} / \mathrm{min}$.

$\mathrm{H}_{2} \mathrm{O}$-temperature-programmed desorption (TPD) was conducted using an automatic multipurpose adsorption instrument TP-5079 (Tianjin Xianquan, China). The pretreated $\left(0.1 \mathrm{~g}\right.$, treated at $300{ }^{\circ} \mathrm{C}$ in $\mathrm{He}$ for $\left.1 \mathrm{~h}\right)$ catalyst was subjected to rehydration 
for $1 \mathrm{~h}$ at $30{ }^{\circ} \mathrm{C}$. After being purged with a He stream $(30 \mathrm{ml} / \mathrm{min})$ at $100{ }^{\circ} \mathrm{C}$ until the base line remained unchanged, the catalyst was heated from 100 to $800{ }^{\circ} \mathrm{C}$ at a rate of $10{ }^{\circ} \mathrm{C} / \mathrm{min}$ to record $\mathrm{H}_{2} \mathrm{O}(\mathrm{m} / \mathrm{z}=18)$ desorption by using a quadrupole mass spectrometer (Hiden Analytical, UK).

The temperature-programmed surface reaction (TPSR) was conducted using an automatic multipurpose adsorption instrument (TP-5079, Tianjin Xianquan, China). The catalyst was first purged with 100 ppm CB, $600 \mathrm{ppm} \mathrm{NH}_{3}$ (if used), $600 \mathrm{ppm} \mathrm{NO}$ (if used), $5 \mathrm{vol} \% \mathrm{O}_{2}$ and $\mathrm{He}$ balance at $80{ }^{\circ} \mathrm{C}$ until the base line remained unchanged (GHSV was $40,000 \mathrm{~h}^{-1}$ ). Thereafter, the catalyst was heated from 100 to $600{ }^{\circ} \mathrm{C}$ at a rate of $5{ }^{\circ} \mathrm{C} / \mathrm{min}$ to record $\mathrm{HCl}(\mathrm{m} / \mathrm{z}=36)$ and $\mathrm{Cl}_{2}(\mathrm{~m} / \mathrm{z}=70)$ desorption using a quadrupole mass spectrometer (Hiden Analytical, UK).

Pyridine adsorbed IR spectroscopy (Py-IR) was conducted using an FT-IR Frontier (PerkinElmer, USA) equipped with a custom-made IR cell. The measurement was carried out in situ and the spectra were recorded at a resolution of $4 \mathrm{~cm}^{-1}$. The catalyst was first heated at a rate of $10{ }^{\circ} \mathrm{C} \min ^{-1}$ to $350{ }^{\circ} \mathrm{C}$ and then cooled to room temperature in a vacuum. Then pyridine vapor was introduced until the adsorption approached saturation. The desorption process was conducted by heating the adsorbed catalyst at a linear heating rate of $10{ }^{\circ} \mathrm{C} \mathrm{min}^{-1}$ to $350{ }^{\circ} \mathrm{C}$.

The quantitative identification of gaseous byproducts was conducted using a calibrated GC/MS system. The detection limits of respective compounds were listed in Table S1.

Table S1 The detection limits of the compounds by the calibrated GC/MS system

\begin{tabular}{cc}
\hline Compounds & Detection limit $\left(\mu \mathrm{g} / \mathrm{m}^{3}\right)$ \\
\hline carbon disulfide & 0.0016 \\
chloromethane & 0.0630 \\
vinyl chloride & 0.0250 \\
chloroethane & 0.0166 \\
dichloromethane & 0.0101 \\
cis-1,2-dichloroethylene & 0.0272 \\
trans-1,2-dichloroethylene & 0.0271 \\
1,2-dichloroethane & 0.0120
\end{tabular}




\begin{tabular}{cc} 
trichloroethylene & 0.0023 \\
1,1,2-trichloroethane & 0.0122 \\
benzene & 0.0053 \\
toluene & 0.0026 \\
benzyl chloride & 0.0535 \\
1,2-dichlorobenzene & 0.0077 \\
1,3-dichlorobenzene & 0.0209 \\
1,4-dichlorobenzene & 0.0024 \\
1,2,4-trichlorobenzene & 0.1325 \\
\hline
\end{tabular}




\section{S2. CALCULATION OF TOF}

TOF was calculated based on the converted mole number of $\mathrm{NO}$ or $\mathrm{CB}$ per second per mole of $\mathrm{V}$, which is refer to the literature ${ }^{1}$.

Reaction condition: $1500 \mathrm{~mL} / \mathrm{min}$ flow; $600 \mathrm{ppm} \mathrm{NO}, 600$ ppm NH $\mathrm{H}_{3}, 100 \mathrm{ppm} \mathrm{CB}$, $5 \% \mathrm{O}_{2}$ and balance $\mathrm{N}_{2}$; catalyst: $2.3 \mathrm{~mL}(2.163 \mathrm{mg})$

The TOF of SCR or CBCO was calculated as following formula:

$$
\mathrm{TOF}=\frac{\mathrm{NO} / \mathrm{CB} \text { concentration } \times \text { flow rate }(\mathrm{mL} / \mathrm{min}) \times \text { conversion }}{60(\mathrm{~s} / \mathrm{min}) \times 22.4(\mathrm{~L} / \mathrm{mol}) \times 10^{3}(\mathrm{~mL} / \mathrm{L}) \times \mathrm{V} \text { content }(\mathrm{mol})}
$$

The $\mathrm{V}$ content was calculated as following formula:

$$
\mathrm{V} \text { content }=\frac{\mathrm{m}_{\text {catalyst }}(\mathrm{g}) \times \mathrm{V} \text { wt } \%}{\mathrm{M}_{\mathrm{V}}(\mathrm{g} / \mathrm{mol})}
$$

where the " $\mathrm{m}_{\text {catalyst }}$ " is indicative of weight of the catalyst, " $\mathrm{Mv}$ " is indicative of relative molecular mass of vanadium and " $\mathrm{V} w \mathrm{t} \%$ " was determined by ICP-OES. 


\section{S3. SUPPLEMENTARY FIGURES AND TABLES}
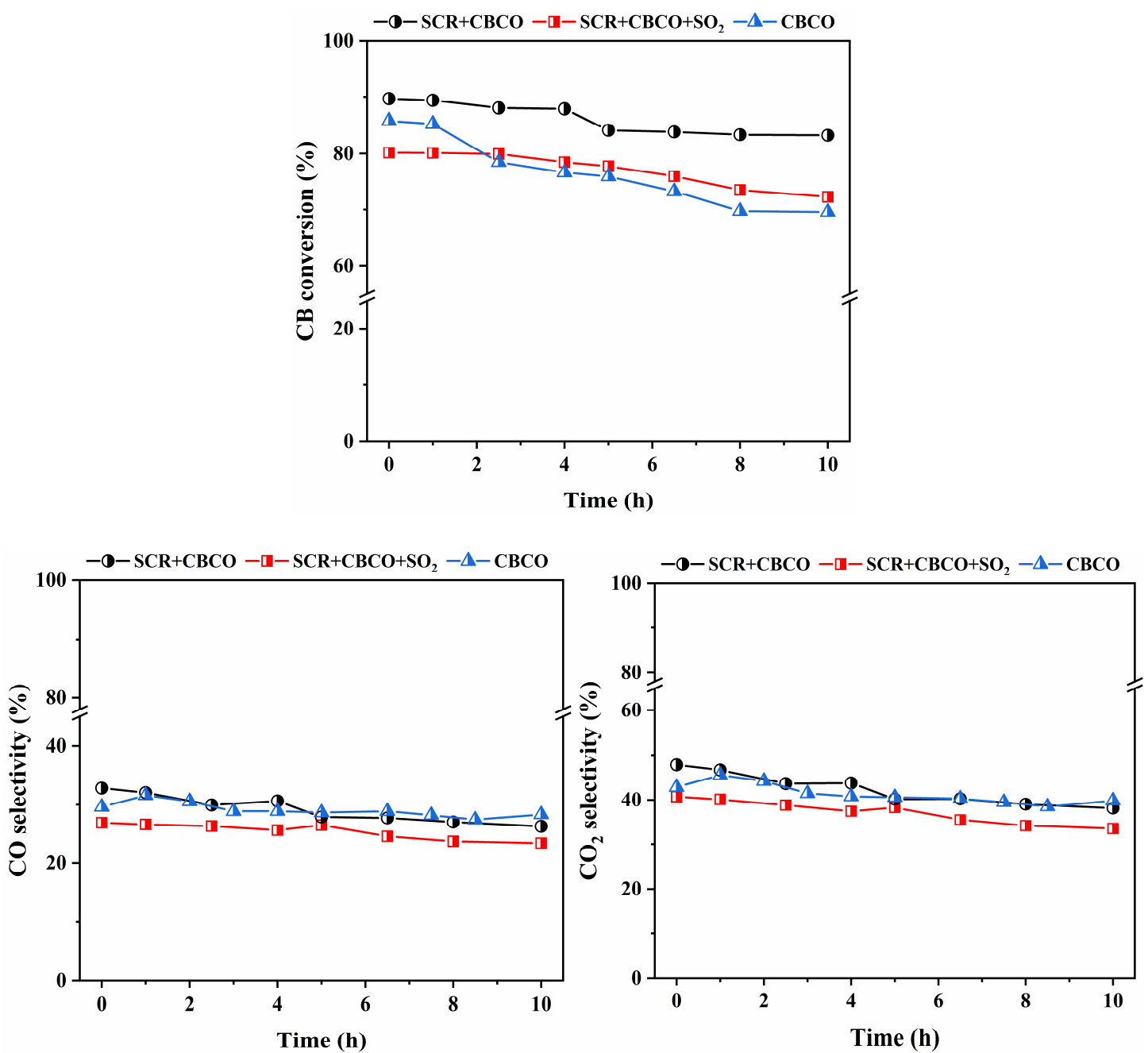

Figure S1. Performance of $10 \mathrm{~h}$ time-on-stream (TOS) stability test on the $\mathrm{V}_{2} \mathrm{O}_{5}-\mathrm{WO}_{3} / \mathrm{TiO}_{2}$ catalyst at $250^{\circ} \mathrm{C}$. Conditions: $\left[\mathrm{NH}_{3}\right]=[\mathrm{NO}]=600 \mathrm{ppm},[\mathrm{CB}]=100 \mathrm{ppm},\left[\mathrm{SO}_{2}\right]=100 \mathrm{ppm},\left[\mathrm{O}_{2}\right]=5 \mathrm{vol} \%$, $\mathrm{N}_{2}$ balance, GHSV $=40,000 \mathrm{~h}^{-1}$. 
Figure S2 illustrates the TG and DTG curves that were used to measure the decomposition temperature of $\mathrm{NH}_{4} \mathrm{Cl}$. For pure $\mathrm{NH}_{4} \mathrm{Cl}$, it began to decompose at $190{ }^{\circ} \mathrm{C}$ and the decomposition rate reached the maximum at $298{ }^{\circ} \mathrm{C} .1 \mathrm{wt} \%$ and $10 \mathrm{wt} \% \mathrm{NH}_{4} \mathrm{Cl}$ was supported on the $\mathrm{V}_{2} \mathrm{O}_{5}-\mathrm{WO}_{3} / \mathrm{TiO}_{2}$ catalyst by wet impregnation. The $10 \mathrm{wt} \%$ $\mathrm{NH}_{4} \mathrm{Cl}$ on the treated catalyst began to decompose earlier at $135^{\circ} \mathrm{C}$ and its maximum decomposition rate appeared at $245{ }^{\circ} \mathrm{C}$, compared with pure $\mathrm{NH}_{4} \mathrm{Cl}$. However, the $\mathrm{NH}_{4} \mathrm{Cl}$ can not completely decompose before around $400{ }^{\circ} \mathrm{C}$. This reveals that the generated inactive $\mathrm{NH}_{4} \mathrm{Cl}$ in the synergistic reaction would partially decompose at selected 200,250 and $300{ }^{\circ} \mathrm{C}$ and small amout of the $\mathrm{NH}_{4} \mathrm{Cl}$ would remain on the catalyst surface, which would not deposit on the catalyst surface and then cause the serious catalyst deactivation.
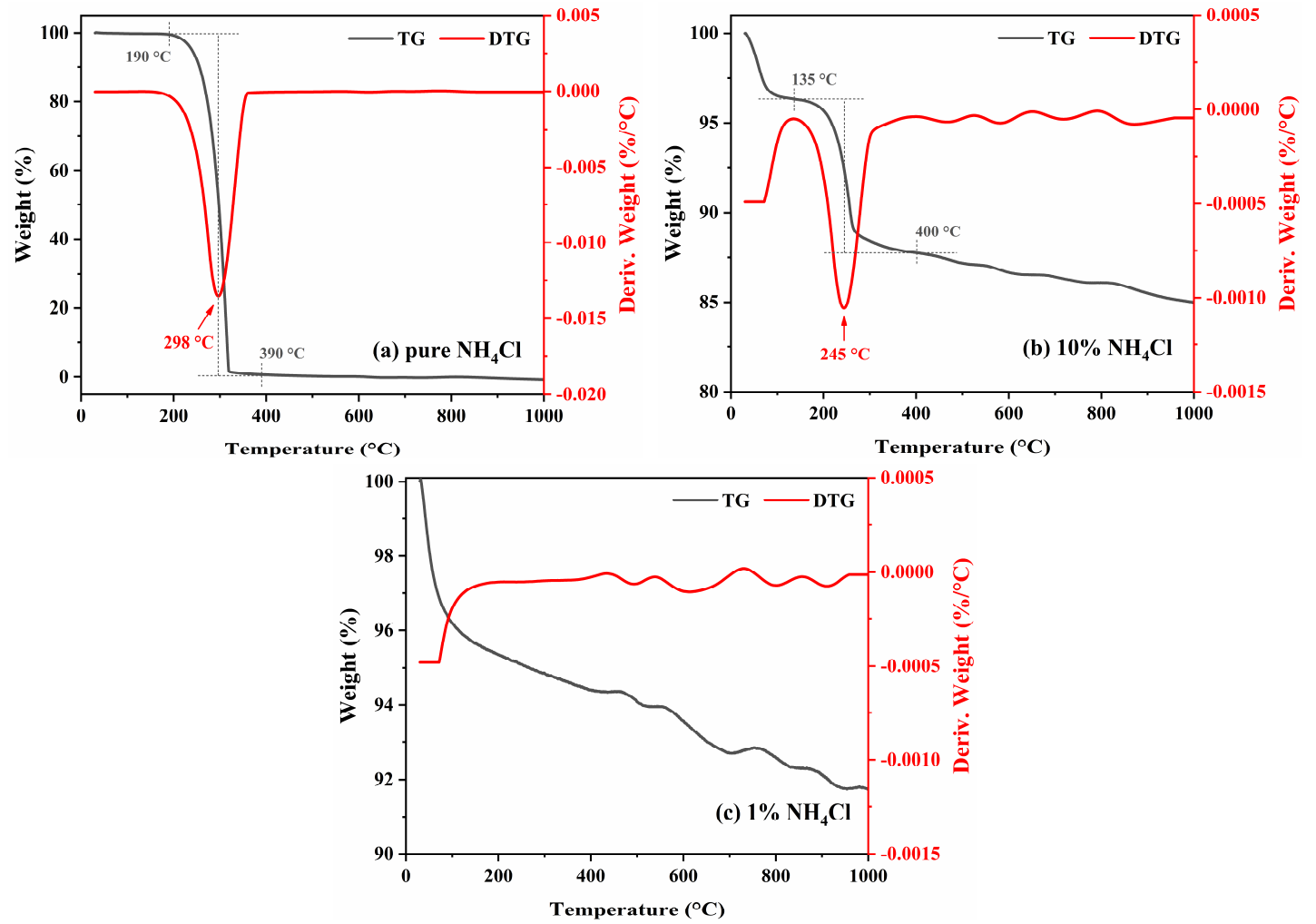

Figure S2. TG and DTG curves of the decomposition temperature of $\mathrm{NH}_{4} \mathrm{Cl}$. 
V2p3/2 XPS spectra illustrated in Figure S3a revealed that the oxidation state of vanadium active species of all catalysts was shown to be $\mathrm{V}^{5+}$. For the fresh catalyst, the average valence of vanadium was measured at 0.34 . After $200{ }^{\circ} \mathrm{C}$ TOS test, this value was slightly increased to 4.70 , and after the TOS tests at 250 and $300{ }^{\circ} \mathrm{C}$, the value decreased to ca. 4.58. These analyses indicated that the oxidation state of vanadium active phase was effectively retained after the TOS tests.

Table S2. Surface atomic concentration and related information of various catalysts from XPS spectra

\begin{tabular}{ccccccc}
\hline \multirow{2}{*}{ Catalysts } & \multicolumn{9}{c}{ Surface atomic concentration } & \multirow{2}{*}{$\mathrm{V}^{4+} /\left(\mathrm{V}^{4+}+\mathrm{V}^{5+}\right)$} & $\begin{array}{c}\text { Average valence of } \\
\text { vanadium }\end{array}$ \\
\cline { 2 - 5 } & $\mathrm{V}$ & $\mathrm{W}$ & $\mathrm{Ti}$ & $\mathrm{O}$ & & 4.70 \\
\hline Used at $200{ }^{\circ} \mathrm{C}$ & 1.54 & 0.73 & 24.39 & 62.50 & 0.30 & 4.58 \\
Used at $250{ }^{\circ} \mathrm{C}$ & 1.78 & 0.78 & 24.59 & 60.79 & 0.42 & 4.57 \\
Used at $300^{\circ} \mathrm{C}$ & 1.65 & 0.78 & 25.27 & 59.90 & 0.43 & 4.66 \\
Fresh & 1.42 & 0.75 & 24.69 & 61.35 & 0.34 & 0.34 \\
\hline
\end{tabular}
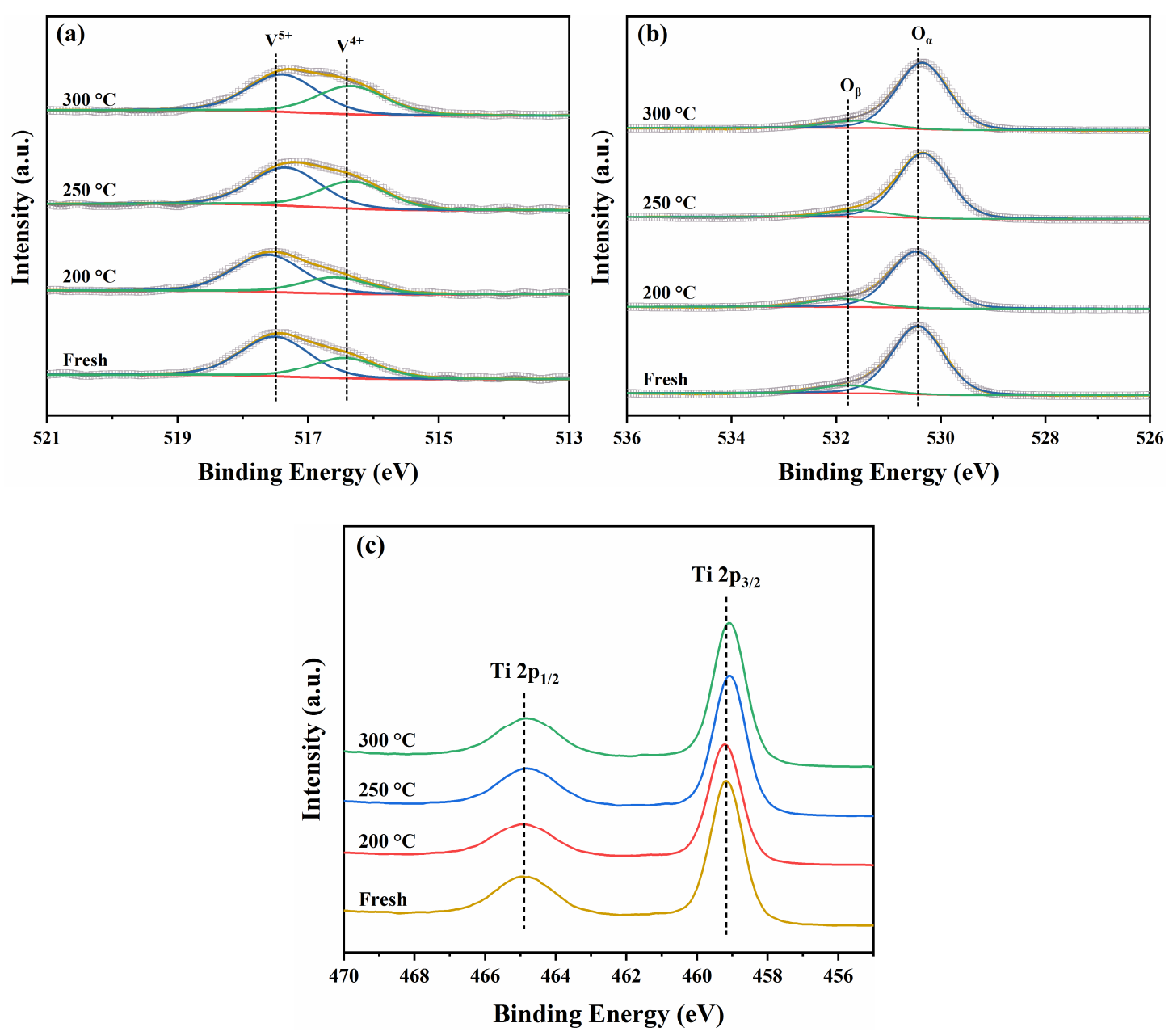

Figure S3. XPS spectra of (a)V 2p $3 / 2$, (b) O 1s and (c) Ti 2p. 
As shown in Figure S4, all the catalysts exhibited the only characteristic peaks of anatase $\mathrm{TiO}_{2}$, suggesting that 10 -hour TOS tests under different temperatures did not change the structure of $\mathrm{V}_{2} \mathrm{O}_{5}-\mathrm{WO}_{3} / \mathrm{TiO}_{2}$ catalyst, even in the presence of $\mathrm{SO}_{2}$.

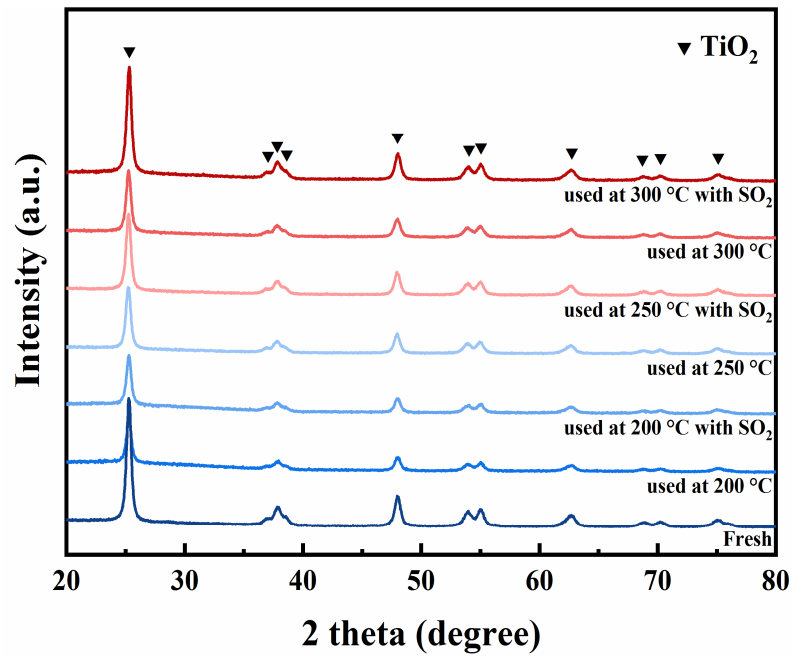

Figure S4. XRD patterns of fresh and used catalysts. 
Figure S5 illustrates the TG and DTG curves of the synergistically reacted catalysts for $10 \mathrm{~h}$ at 200,250 and $300{ }^{\circ} \mathrm{C}$. The DTG valleys emerged at around $240{ }^{\circ} \mathrm{C}$ corresponded to the decomposition of $\left(\mathrm{NH}_{4}\right)_{2} \mathrm{SO}_{4}$, and the valleys at around $390{ }^{\circ} \mathrm{C}$ originated from the decomposition of $\mathrm{NH}_{4} \mathrm{HSO}_{4}{ }^{2,3}$. In the used catalysts at 200 and $250{ }^{\circ} \mathrm{C}$, the characteristic valleys of $\left(\mathrm{NH}_{4}\right)_{2} \mathrm{SO}_{4}$ and $\mathrm{NH}_{4} \mathrm{HSO}_{4}$ both appeared. These results all suggested that the $\mathrm{V}_{2} \mathrm{O}_{5}-\mathrm{WO}_{3} / \mathrm{TiO}_{2}$ catalyst had been sulfated in the presence of $\mathrm{SO}_{2}$. However, in the used catalyst at $300^{\circ} \mathrm{C}$, these valleys were absent.
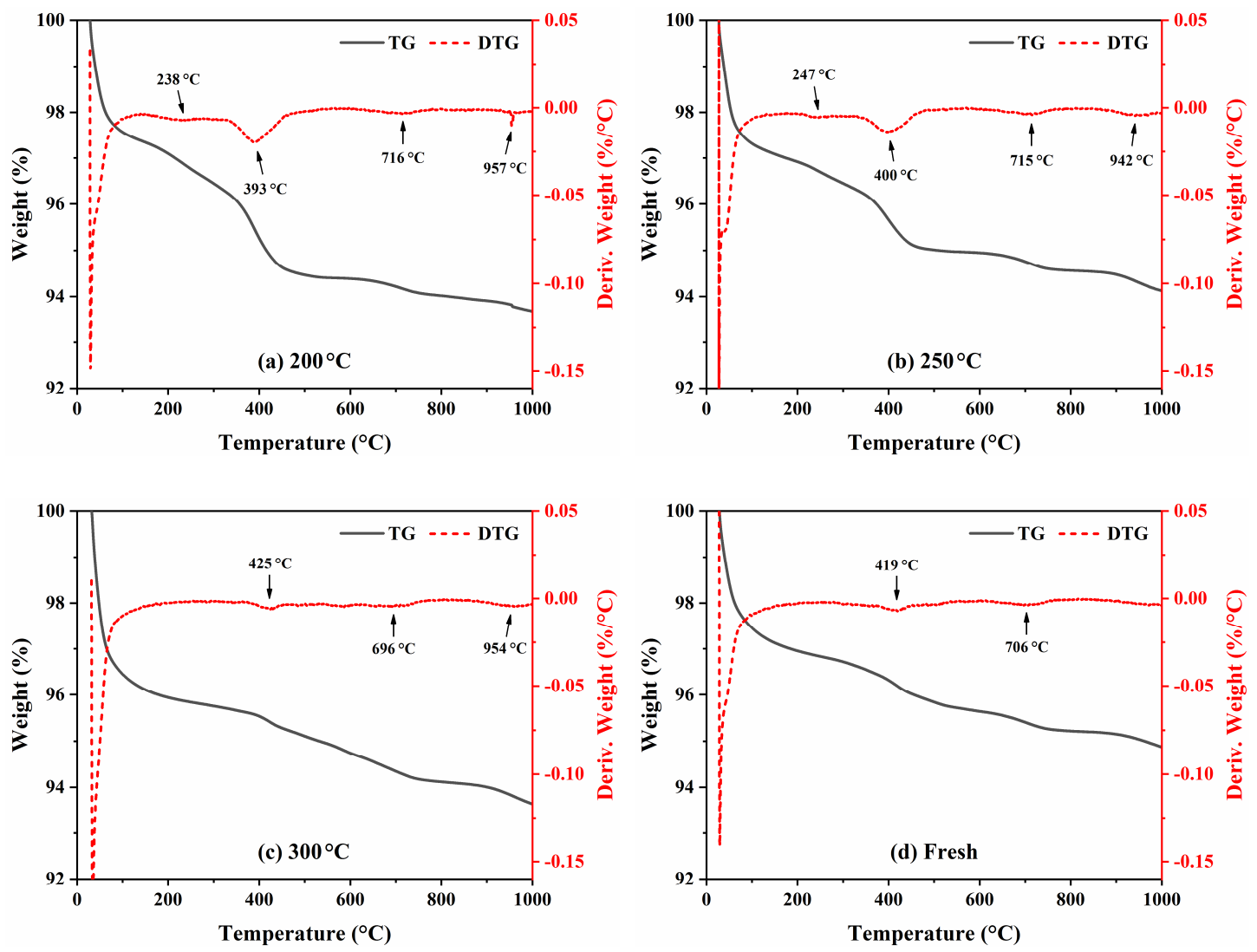

Figure S5. TG and DTG curves of fresh and used $\mathrm{V}_{2} \mathrm{O}_{5}-\mathrm{WO}_{3} / \mathrm{TiO}_{2}$ catalysts. 
Figure S6 illustrates the Py-IR spectra that were used to evaluate the changes in Brønsted and Lewis acidity after $\mathrm{V}_{2} \mathrm{O}_{5}-\mathrm{WO}_{3} / \mathrm{TiO}_{2}$ catalyst sulfated at $200{ }^{\circ} \mathrm{C}$ for 10 hours (reaction condition: $600 \mathrm{ppm} \mathrm{NH}_{3}, 500 \mathrm{pm} \mathrm{SO}_{2}, 5$ vol\% $\mathrm{O}_{2}$ and balance $\mathrm{N}_{2}$ ). The bands at 1635 and $1545 \mathrm{~cm}^{-1}$ originated from pyridine adsorbed onto Brønsted acid sites, and those at 1612 and $1445 \mathrm{~cm}^{-1}$ were attributed to pyridine adsorbed onto Lewis acid sites, and the band at $1490 \mathrm{~cm}^{-1}$ were due to the pyridine adsorbed onto both Lewis and Brønsted acid sites ${ }^{4,5}$. As shown in Figure S6 and Table S3, the Brønsted acidity was significantly enhanced by the sulfation. This would induce the over-adsorption of CB, the coverage of which on the catalyst surface would increase the chance of $\mathrm{Cl}$ attack, thus promoting the chlorination reaction over the catalyst.

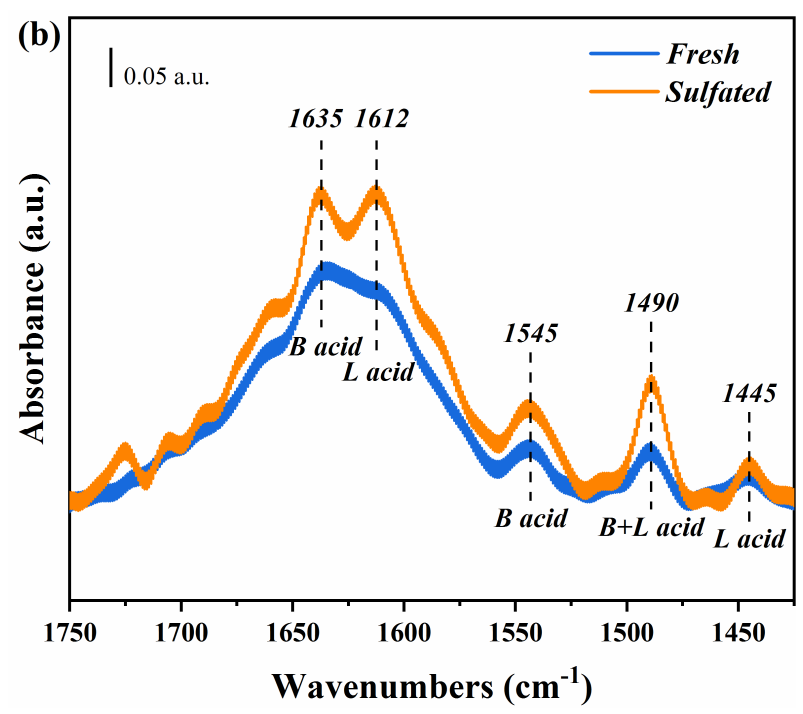

Figure S6. Py-IR spectra of the fresh and sulfated $\mathrm{V}_{2} \mathrm{O}_{5}-\mathrm{WO}_{3} / \mathrm{TiO}_{2}$ catalyst.

Table S3. Quantitative amount of the acidity for fresh and sulfated $\mathrm{V}_{2} \mathrm{O}_{5}-\mathrm{WO}_{3} / \mathrm{TiO}_{2}$ catalyst

\begin{tabular}{ccc}
\hline \multirow{2}{*}{ Acids } & \multicolumn{2}{c}{ Amount of the acidity $(\mathrm{mmol} / \mathrm{g})$} \\
\cline { 2 - 3 } & Fresh & Sulfated \\
\hline Brønsted acid $\left(1545 \mathrm{~cm}^{-1}\right)$ & 0.01096 & 0.02693 \\
Lewis acid $\left(1445 \mathrm{~cm}^{-1}\right)$ & 0.00516 & 0.00756 \\
\hline
\end{tabular}



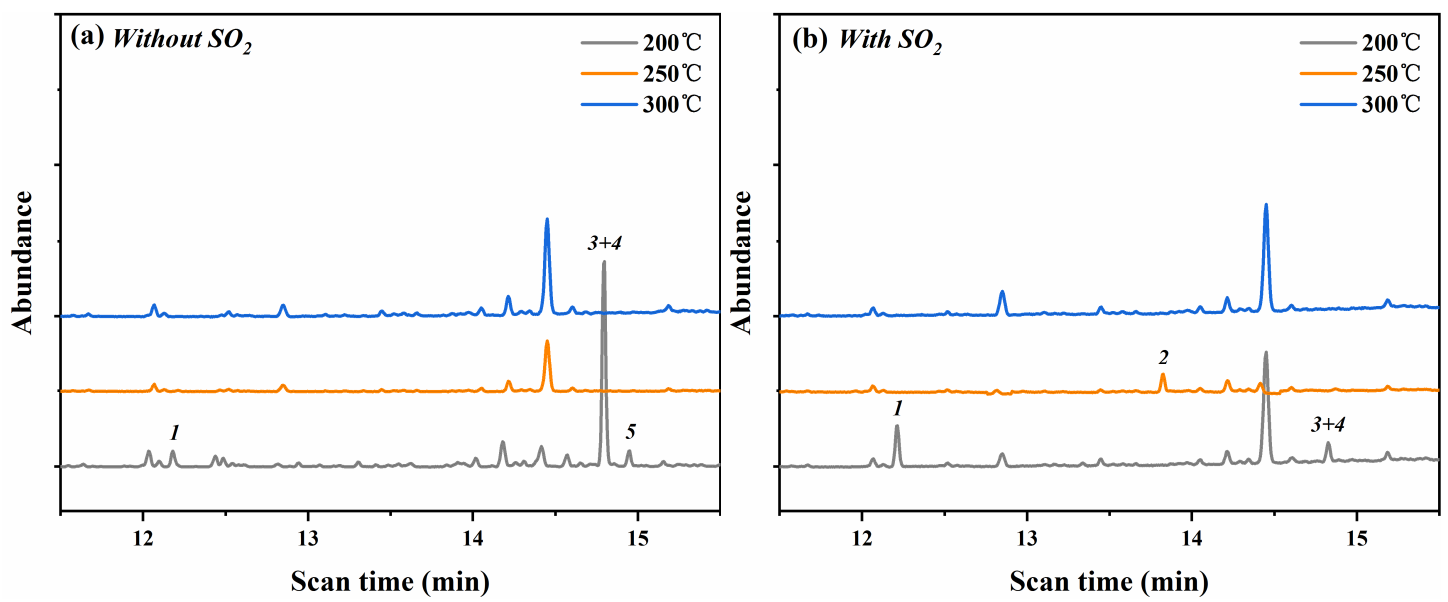

Figure S7. GC/MS qualitative analyses of surficial semi-volatile organics produced on $\mathrm{V}_{2} \mathrm{O}_{5}$ $\mathrm{WO}_{3} / \mathrm{TiO}_{2}$ catalyst at $200,250,300{ }^{\circ} \mathrm{C}$ (a) without or (b) with $\mathrm{SO}_{2}$ (Note: The labels in this Figure refer to Table 2; other unlabeled high peaks represent polysiloxane originated from the loss of stationary phase in the chromatographic column). 
Table S4. GC/MS quantitative analyses of selected gaseous compounds produced on $\mathrm{V}_{2} \mathrm{O}_{5^{-}}$ $\mathrm{WO}_{3} / \mathrm{TiO}_{2}$ catalyst at $250{ }^{\circ} \mathrm{C}$

\begin{tabular}{cccc}
\hline \multirow{2}{*}{ Species } & \multicolumn{3}{c}{ Concentrations $\left(\mathrm{ug} / \mathrm{m}^{3}\right)$} \\
\cline { 2 - 4 } chloromethane & $\mathrm{CBCO}$ & $\mathrm{SCR}+\mathrm{CBCO}$ & $\mathrm{SCR}+\mathrm{CBCO}+\mathrm{SO}_{2}$ \\
vinyl chloride & 13.16 & 20.96 & 452.00 \\
chloroethane & 0.06 & 2.05 & 1.80 \\
dichloromethane & 8.53 & 0.71 & 18.70 \\
cis-1,2-dichloroethylene & 1.66 & 7.63 & 5.22 \\
trans-1,2-dichloroethylene & 0.92 & 1.46 & 22.53 \\
1,2-dichloroethane & 3.06 & 0.80 & 198.80 \\
trichloroethylene & 0.91 & 6.96 & 2.42 \\
1,1,2-trichloroethane & 0.00 & 0.85 & 7.37 \\
\hline benzene & 0.68 & 9.36 & 314.10 \\
\hline toluene & 26.57 & 2.52 & 10.92 \\
benzyl chloride & 13.24 & 35.80 & 9.75 \\
1,2-dichlorobenzene & 0.87 & 8.15 & 6.53 \\
1,3-dichlorobenzene & 24.07 & 0.00 & 5.83 \\
1,4-dichlorobenzene & 14.14 & 0.00 & 2.13 \\
\hline 1,2,4-trichlorobenzene & 0.00 & 1.55 & 13.86 \\
\hline
\end{tabular}

The illustrated and listed concentrations of selected gaseous compounds in Figure 6 and Table S4 were calibrated with the corresponding CB conversions as following formula:

$$
\text { illustrated and listed concentration }=\frac{\text { measured concentration }}{\text { corresponding CB conversion }}
$$


Table S5. The I-TEQ concentrations of the 2,3,7,8-substituted PCDD/F congeners at $250{ }^{\circ} \mathrm{C}$

\begin{tabular}{|c|c|c|c|c|c|c|}
\hline & \multicolumn{3}{|c|}{ Gas phase (ng I-TEQ $\mathrm{Nm}^{-3}$ ) } & \multicolumn{3}{|c|}{ Solid phase (ng I-TEQ g ${ }^{-1}$ ) } \\
\hline & $\mathrm{CBCO}$ & $\mathrm{SCR}+\mathrm{CBCO}$ & $\mathrm{SCR}+\mathrm{CBCO}+\mathrm{SO}_{2}$ & $\mathrm{CBCO}$ & $\mathrm{SCR}+\mathrm{CBCO}$ & $\mathrm{SCR}+\mathrm{CBCO}+\mathrm{SO}_{2}$ \\
\hline 2378TCDD & 0.00000 & 0.00000 & 0.00000 & 0.00065 & 0.00000 & 0.00000 \\
\hline 12378PeCDD & 0.00251 & 0.01039 & 0.00387 & 0.00074 & 0.00072 & 0.00125 \\
\hline $123478 \mathrm{HxCDD}$ & 0.00060 & 0.00148 & 0.00082 & 0.00015 & 0.00009 & 0.00017 \\
\hline $123678 \mathrm{HxCDD}$ & 0.00084 & 0.00285 & 0.00131 & 0.00022 & 0.00019 & 0.00039 \\
\hline 123789HxCDD & 0.00074 & 0.00110 & 0.00093 & 0.00016 & 0.00018 & 0.00020 \\
\hline $1234678 \mathrm{HpCDD}$ & 0.00034 & 0.00082 & 0.00067 & 0.00011 & 0.00013 & 0.00011 \\
\hline OCDD & 0.00011 & 0.00021 & 0.00016 & 0.00003 & 0.00003 & 0.00003 \\
\hline $2378 \mathrm{TCDF}$ & 0.00071 & 0.00287 & 0.00083 & 0.00048 & 0.00022 & 0.00039 \\
\hline $12378 \mathrm{PeCDF}$ & 0.00076 & 0.00109 & 0.00072 & 0.00017 & 0.00014 & 0.00019 \\
\hline 23478PeCDF & 0.00573 & 0.01111 & 0.00644 & 0.00229 & 0.00130 & 0.00197 \\
\hline $123478 \mathrm{HxCDF}$ & 0.00231 & 0.00549 & 0.00379 & 0.00059 & 0.00066 & 0.00091 \\
\hline $123678 \mathrm{HxCDF}$ & 0.00286 & 0.00536 & 0.00447 & 0.00071 & 0.00078 & 0.00089 \\
\hline $123789 \mathrm{HxCDF}$ & 0.00081 & 0.00086 & 0.00068 & 0.00018 & 0.00013 & 0.00014 \\
\hline
\end{tabular}




\begin{tabular}{cllllll}
$234678 \mathrm{HxCDF}$ & 0.00349 & 0.00536 & 0.00460 & 0.00087 & 0.00076 & 0.00098 \\
$1234678 \mathrm{HpCDF}$ & 0.00077 & 0.00213 & 0.00175 & 0.00018 & 0.00027 & 0.00033 \\
$1234789 \mathrm{HpCDF}$ & 0.00015 & 0.00000 & 0.00000 & 0.00003 & 0.00004 & 0.00005 \\
OCDF & 0.00007 & 0.00026 & 0.00022 & 0.00002 & 0.00003 & 0.00004 \\
\hline Total & 0.02282 & 0.05137 & 0.03126 & 0.00757 & 0.00567 & 0.00804 \\
\hline
\end{tabular}

EPA's International Toxicity Equivalent Factor (I-TEF) was used for I-TEQ calculation. 


\section{REFERENCES}

1. Gu, Y.; Cai, T.; Gao, X.; Xia, H.; Sun, W.; Zhao, J.; Dai, Q.; Wang, X., Catalytic combustion of chlorinated aromatics over $\mathrm{WO}_{\mathrm{x}} / \mathrm{CeO}_{2}$ catalysts at low temperature. Appl. Catal., B 2019, 248, 264-276.

2. Nam, I. S.; Eldridge, J. W.; Kittrell, J. R., Deactivation of a vanadia-alumina catalyst for nitric oxide reduction by ammonia. Ind. Eng. Chem. Prod. Res. Dev. 1986, 25, (2), 192-197.

3. Zhu, Z.; Niu, H.; Liu, Z.; Liu, S., Decomposition and Reactivity of $\mathrm{NH}_{4} \mathrm{HSO}_{4}$ on $\mathrm{V}_{2} \mathrm{O}_{5} /$ AC Catalysts Used for NO Reduction with Ammonia. J. Catal. 2000, 195, (2), $268-278$.

4. Wang, Y.; Tao, Z.; Wu, B.; Xu, J.; Huo, C.; Li, K.; Chen, H.; Yang, Y.; Li, Y., Effect of metal precursors on the performance of $\mathrm{Pt} / \mathrm{ZSM}-22$ catalysts for $n$-hexadecane hydroisomerization. J. Catal. 2015, 322, 1-13.

5. Sun, P.; Wang, W.; Weng, X.; Dai, X.; Wu, Z., Alkali Potassium Induced $\mathrm{HCl} / \mathrm{CO}_{2}$ Selectivity Enhancement and Chlorination Reaction Inhibition for Catalytic Oxidation of Chloroaromatics. Environ. Sci. Technol. 2018, 52, (11), 6438-6447. 